\title{
The Incidence of Gonorrhea in Belgrade in the Period 2010 - 2014
}

\author{
Milan BJEKIĆ ${ }^{1}$, Hristina VLAJINAC ${ }^{2}$, Biljana BEGOVIĆ-VUKSANOVIĆ 3 \\ ${ }^{1}$ City Institute for Skin and Venereal Diseases, Belgrade, Serbia \\ ${ }^{2}$ Institute of Epidemiology, School of Medicine, University of Belgrade, Belgrade \\ ${ }^{3}$ City Institute for Public Health, Belgrade \\ ${ }^{*}$ Correspondence: Milan Bjekić, E-mail: milinkovski@gmail.com
}

DE GRUYTER

UDC 616.973(497.11 Beograd)"2010/2014"

\begin{abstract}
The World Health Organization (WHO) estimated that in 2008 there were 106.1 million newly registered cases of gonorrhea among adults worldwide. Of these cases, 3.4 million were in the WHO European Region. In the European Union and European Economic Area, the overall incidence of reported cases was 15.3 per 100.000 population in 2012; the highest rate (45.4 per 100.000) was observed in the United Kingdom, while low rates ( $<5$ per 100.000) were generally reported in the Central and Eastern Europe. In 2012, low incidence of gonorrhea (1.49/100.000) was reported in Serbia, as well.

The purpose of this study was to report on the epidemiology of gonorrhea in a Belgrade population (about 1.5 million inhabitants) during the period 2010 - 2014, and to discuss data on gonorrhea rates in the European Union.

In Serbia it is mandatory to report gonorrhea, and all reports of culture-proved gonorrhea are sent to the City Institute for Public Health in Belgrade. These reports were used as the source for data analysis of gonorrhea incidence. Incidence rates were calculated using data from the 2011 population census in Serbia for Belgrade population. Age-adjusted annual incidence rates were carried out by a direct method using the "world population" as a standard.

During the 2010 - 2014 period, the average gonorrhea incidence in Belgrade population was 9.2 per 100.000 in men, and 1.9 per 100.000 in women. The incidence was highest in men and women aged $20-29$ years. In all age groups gonorrhea incidence was higher in men than in women, the average male/female ratio being 4.8. In both sexes, the incidence of gonorrhea was highest in persons who had never married, with secondary education and unemployed. Out of 357 men with gonorrhea, 92 (25.77\%) were self-reported homosexuals.
\end{abstract}

\section{Key words}

Gonorrhea; Incidence; Age Distribution; Sex Distribution; Homosexuality, Male; Sexual Behavior

G onorrhea is a sexually transmitted disease I caused by the gram-negative bacterium Neisseria gonorrhoeae. Infection predominantly involves the columnar epithelium of the urethra, endocervix, rectum, pharynx and conjunctiva. It is commonly transmitted through sexual contact (i.e. genitalgenital, genital-anorectal, oro-genital or oro-anal) or vertically from mother to infant.

The World Health Organization (WHO) estimated that in 2008 there were 106.1 million new cases of gonorrhea among adults worldwide (1). Of these, 3.4 million were in the WHO European Region. In the European Union and
European Economic Area, the overall incidence of reported cases was 15.3 per 100.000 people in 2012. The highest rates were observed in the United Kingdom (45.4 per 100.000), while low rates $(<5$ per 100.000$)$ were generally reported in the Central and Eastern Europe. In 2012, there was a low reported incidence of gonorrhea in Serbia $(1.49 / 100.000)$, as well.

The purpose of this study was to report on the epidemiology of gonorrhea in Belgrade (about 1.5 million inhabitants) during the period 2010 2014, and to discuss the data in the light of changes in gonorrhea incidence in the European Union. 


\section{Material and methods}

Reporting of gonorrhea is required in Serbia, and in Belgrade all reports of laboratory proven cases of gonorrhea are sent to the City Institute for Public Health. These reports were used as the source of information on gonorrhea incidence.

Gonorrhea incidence rates were based on data from the 2011 Serbian census for Belgrade population. Age-adjustment of annual incidence rates was carried out using a direct method of "world population" as a standard (4).

\section{Results}

A total of 438 gonorrhea cases, 357 males and 81 females, were newly registered at the City Institute for Public Health in Belgrade during 2010 - 2014. The incidence in males ranged from 4.8 to 14.0 per 100.000 , the average incidence being 9.2 per 100.000. In females, the incidence ranged from 0.3 to 3.1 per 100.000 , and the average incidence was 1.9 per 100.000 (Figure 1). The age-adjusted average incidence was 9.4 per 100.000 in males and 2.2 per 100.000 in females.

The incidence of gonorrhea in Belgrade was highest in men and women aged 20 - 29 years. In both sexes the lowest incidence was in persons aged 50 and over, and in children $\leq 19$ years of age. In all age groups, gonorrhea incidence was higher in men than in women. The male/female ratio ranged from 2.4 to 6.5 , the average ratio being 4.8 (Table 1 ).

In both sexes gonorrhea incidence was highest in persons who had never married, with secondary education, and unemployed (Table 2). Out of 357 men with gonorrhea, $92(25.77 \%)$ were self-reported homosexuals.

\section{Discussion}

A dramatically decreasing trend of gonorrhea incidence in Belgrade was observed in the last two decades of the XX century (53 per 100.000 in 1988 and 8 per 100.000 in 2000) $(5,6)$. The incidence of gonorrhea in Belgrade continued to decline in the first decade of the new millennium, when it was under 5 per 100.000 inhabitants (6). However, since 2011, the incidence has increased from 2.47 per 100.000 in 2010 to 8.25 in 2013, and 7.17 per 100.000 in 2014 .

A similar pattern of gonorrhea incidence in the new millennium was also observed in the European Union. A decreasing trend of gonorrhea incidence during the first decade (the rate was 16.6 per 100.000 in 2003, and 9.65 per 100.000 in 2008), was followed by an increase (2). Since 2008, the rate of gonorrhea

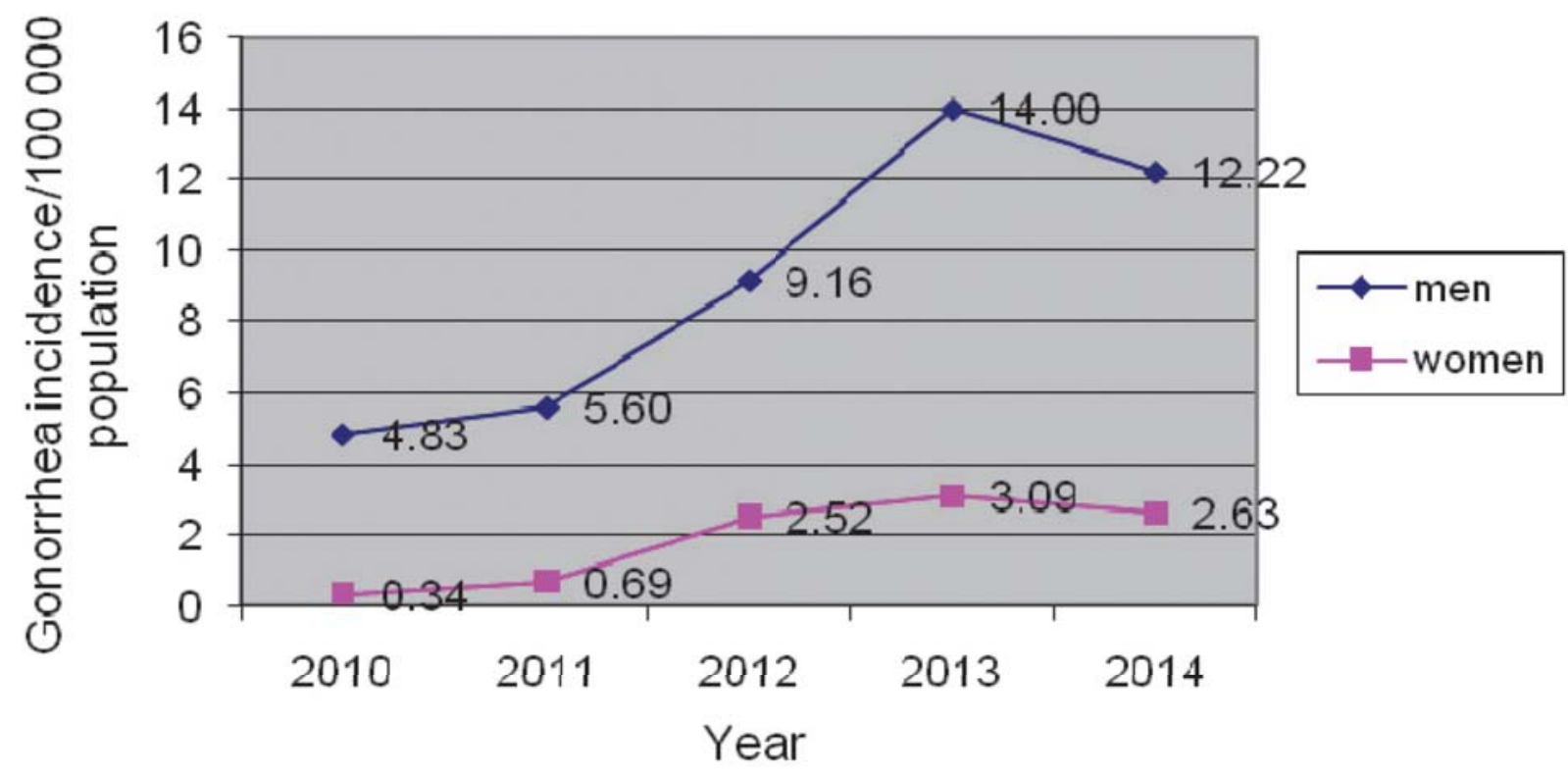

Figure 1. Sex distribution of gonorrhea incidence in Belgrade in 2010 - 2014 
Table 1. Total number of gonorrhea cases and average incidence (per100.000) distributed by age, sex, and male to female ratio, Belgrade 2010 - 2014

\begin{tabular}{|c|c|c|c|c|c|}
\hline \multirow{2}{*}{ Age group } & \multicolumn{2}{|c|}{ Men } & \multicolumn{2}{|c|}{ Women } & \multirow{2}{*}{$\begin{array}{l}\text { Sex ratio } \\
\text { Male/femal }\end{array}$} \\
\hline & $\begin{array}{l}\text { Number } \\
\text { of cases }\end{array}$ & $\begin{array}{l}\text { Average } \\
\text { incidence }\end{array}$ & $\begin{array}{l}\text { Number } \\
\text { of cases }\end{array}$ & $\begin{array}{l}\text { Average } \\
\text { incidence }\end{array}$ & \\
\hline$\leq 19$ & 18 & 2.2 & 7 & 0.9 & 2.4 \\
\hline $20-29$ & 148 & 26.9 & 40 & 7.1 & 3.8 \\
\hline $30-39$ & 124 & 19.8 & 21 & 3.2 & 6.2 \\
\hline $40-49$ & 37 & 7.1 & 6 & 1.1 & 6.5 \\
\hline $50+$ & 30 & 2.1 & 7 & 0.4 & 5.3 \\
\hline Total & 357 & 9.1 & 81 & 1.9 & 4.8 \\
\hline
\end{tabular}

increased by 62\%: from 10 to 16 per 100.000 in 2012. The trend of gonorrhea in the European Union varies among countries. Countries which reported high rates in the 1990, such as Bulgaria, Romania and the Czech Republic, reported a decreasing or stable trend. However, other countries (e.g. Denmark, Lithuania, Ireland and the United Kingdom) reported an increasing incidence, especially since 2008 (2).

In 2012, the highest rates were observed in the United Kingdom (45.4/100.000), Latvia (29.4/100.000), Ireland (24.2/100.000) and Estonia $(15.7 / 100.000)$, and the lowest $(\leq 1.5 / 100000)$ in Bulgaria, Croatia, Luxembourg, Portugal and Serbia $(2,3)$.

There is no clear explanation for the declining trends of gonorrhea in Belgrade during the last two decades of the XX century, but it may reflect changes in healthcare systems, including more private offices, and therefore substantially increased number of unreported infections. Also, the increasing number of private pharmacies has allowed antibiotics without prescriptions and self-treatment, which may mask the infection and the diagnosis. The decreasing trend of gonorrhea incidence in 1990s could also be, at least partly, explained by the changes in sexual behavior in response to the AIDS epidemic, especially among men who have sex with men (MSM). The change in sexual behavior is characterized by reduction in the number of partners and safer sexual practice (7).

As already stated, the recent increase of gonorrhea incidence in Belgrade during 2010 - 2014 is similar to that seen in many other European countries. In Europe, it may partially be attributed to increased use of more sensitive diagnostic tests, such as Nucleic Acid Amplification Tests (NAATs) and changes in testing policies including testing at multiple anatomical sites (e.g. rectum, pharynx) among MSM (8). At the same time, more successful antiretroviral therapy has decreased the concern about HIV infection, and high risk behavior increased again especially among homosexual men (9).

The increase of gonorrhea incidence in Belgrade may be explained by the fact that the first Counseling Department for Sexually Transmitted Diseases at the City Institute for Skin and Venereal diseases in Belgrade was established in 2008, which is intended for patients without referral by their GP. The Department is friendly to vulnerable groups (MSM, patients who live with HIV, sex workers) and partner notifications are more effective. At the same time, because of unfavorable economic conditions, the number of patients who can afford private physicians has decreased as well as the number of unreported cases. During 2010 - 2014, the majority of registered 
Table 2. Total number of gonorrhea cases and average incidence (per 100.000), distributed by marital status, education and working status, Belgrade 2010 - 2014

\begin{tabular}{|c|c|c|c|c|}
\hline \multirow[b]{2}{*}{ Characteristic } & \multicolumn{2}{|c|}{ Men } & \multicolumn{2}{|c|}{ Women } \\
\hline & $\begin{array}{l}\text { Total number } \\
\text { of cases }\end{array}$ & $\begin{array}{l}\text { Average } \\
\text { incidence }\end{array}$ & $\begin{array}{l}\text { Total number } \\
\text { of cases }\end{array}$ & $\begin{array}{l}\text { Average } \\
\text { incidence }\end{array}$ \\
\hline \multicolumn{5}{|l|}{ Marital status } \\
\hline Never married & 286 & 24.6 & 56 & 5.4 \\
\hline Married & 63 & 3.4 & 23 & 1.2 \\
\hline Divorced & 8 & 5.1 & 2 & 0.7 \\
\hline
\end{tabular}

Education

\begin{tabular}{lcccc}
\hline$\leq$ Elementary & 46 & 9.2 & 16 & 1.8 \\
\hline Secondary & 282 & 14.9 & 61 & 3.3 \\
\hline High & 29 & 4.5 & 4 & 0.5 \\
\hline
\end{tabular}

Working status

\begin{tabular}{lcccc}
\hline Employed & 156 & 10.0 & 41 & 2.9 \\
\hline Unemployed & 133 & 38.1 & 24 & 8.1 \\
\hline Student & 60 & 17.7 & 15 & 4.0 \\
\hline Retired & 8 & 1.0 & 1 & 0.1 \\
\hline
\end{tabular}

gonorrhea cases in Belgrade (95\%) came right to the City Institute for Skin and Venereal Diseases.

The only laboratory test for the diagnosis of gonorrhea that is used in the afore-named Department is direct microscopy of Gram- or methylene blue stained smear. Microscopy has good sensitivity $(\geq 95 \%)$ and specificity in symptomatic men with urethral discharge, but poor sensitivity in asymptomatic men and in endocervical infections $(\leq 55 \%)$ or in rectal infections $(\leq 40 \%)$. However, microscopy is not recommended for identification of pharyngeal infection $(10,11)$. Cultures appropriate for endocervical, urethral, rectal and pharyngeal specimens have not routinely been performed due to technical limitations. NAATs is a diagnostic tool for gonorrhea which is not available in public healthcare services in Serbia, and this method is more sensitive than culture, offering testing on a wider range of different types of specimens. Moreover, it is less demanding in specimen's quality, transportation and storage of specimens (12).

A higher incidence of gonorrhea in men than in women in Belgrade and in European Union (2), may be explained by differences in the sexual behavior of men and women, and by sex differences in clinical manifestations of the disease. It is well known that homosexual men are more vulnerable to sexually transmitted infections, including gonorrhea. More 
than $1 / 4$ of men with gonorrhea in Belgrade are selfreported homosexuals. Men who have sex with men account for $38 \%$ of cases reported in 2012 in the European Union (2).

In the present study, the highest incidence of gonorrhea among men and women, was established in the age group $20-29$, which is in line with results from the European Union (2). The association of young age with higher gonorrhea incidence rate may be explained by age-related sexual behavior and biological characteristics of the host-pathogen interactions (13).

According to our results, in both sexes gonorrhea infection was most frequent in persons who had never married, with secondary education, and were unemployed. Low education level, young age and low socioeconomic status were found to be positively related to gonococcal infection (14).

The critical feature of this analysis is data accuracy, since the number of gonorrhea cases in Belgrade could have been underestimated for several reasons: there is a possibility that some patients did not visit a physician, which some physicians did not report all cases, and that diagnosis of gonorrhea sometimes failed because of the lack of adequate laboratory feasibilities.

\section{Acknowledgement}

This study was supported by the Ministry of Science and Technology of Serbia, through Contract No. 175042 (2011 - 2014).

\section{Abbreviations}

WHO - World Health Organization

AIDS - acquired immunodeficiency syndrome

MSM - men who have sex with men

NAATs - nucleic acid amplification tests

HIV - human immunodeficiency virus

\section{References}

1. World Health Organization. Global incidence and prevalence of selected curable STI-2008. Geneva: World Health Organization; 2008 [cited 2015 Jul 4]. Available from: http://www.who.int/ reproductivehealth/publications/rtis/2008_STI_estimates.pdf

2. European Centre for Disease Prevention and Control. Sexually transmitted infections in Europe 2012. Stockholm: ECDC; 2014. p. 15-22.

3. Institute of Public Health of Serbia „Dr Milan Jovanovic Batut“. Center for Disease Control and Prevention: Report of infectious diseases in the Republic of Serbia in 2014. Belgrade: Institute of Public Health of Serbia „Dr Milan Jovanovic Batut“; 2015. p. 75-84.

4. Ahmad OB, Boschi-Pinto C, Lopez AD, Murray CJL, Lozano R, Inoue M. Age standardization of rates: a new WHO Standard, GPE Discussion Paper Series: No.31. Geneva: EIP/GPE/EBD, World Health Organization; 2001 [cited 2015 Jul 4]. Available from: http://www.who.int/healthinfo/paper31.pdf

5. Bjekić M, Vlajinac H, Šipetić S, Kocev N. Trends of gonorrhoea and early syphilis in Belgrade, 1985-1999. Sex Transm Infect 2001;77:387-8.

6. Center for Disease Control and Prevention. Report of infectious diseases in Belgrade in 2010. Belgrade: City Institute of Public Health of Belgrade; 2010. p. 49.

7. Johnson AM, Gill ON. Evidence for recent changes in sexual behaviour in homosexual men in England and Wells. Philos Trans R Soc Lond B Biol Sci 1989;325:153-61.

8. Schachter J, Moncada J, Liska S, Shayevich C, Klausner JD. Nucleic acid amplification tests in the diagnosis of chlamydial and gonococcal infections in the oropharynx and rectum in men who have sex with men. Sex Transm Dis 2008;35:637-42.

9. Katz MH, Schwarcz SK, Kellogg TA, Klausner JD, Dilley JW, Gibson S, et al. Impact of highly active antiretroviral treatment on HIV seroincidence among men who have sex with men: San Francisco. Am J Public Health 2002;92:388-94.

10. Sherrard J, Barlow D. Gonorrhoea in men: clinical and diagnostic aspects. Genitourin Med 1996;72:422-6.

11. Barlow D, Phillips I. Gonorrhoea in women. Diagnostic, clinical and laboratory aspects. Lancet 1978;1(8067):761-4.

12. Whiley DM, Garland SM, Hartnett G, Lum G, Smith DW, Tabrizi SN, et al. Exploring 'best practice' for nucleic acid detection of Neisseria gonorrhoeae. Sex Health 2008;5:17-23.

13. Hook EW, Reichart CA, Upchurch DM, Ray P, Celentano D, Quinn TC. Comparative behavioral epidemiology of gonococcal and chlamydial infections among patients attending a Baltimore, Maryland, Sexually transmitted disease clinic. Am J Epidemiol 1992;136:662-72.

14. Bjekić M, Vlajinac H, Šipetić S, Marinković J. Risk factors for gonorrhoea: case-control study. Genitourin Med 1997;73:518-21. 


\section{Incidencija gonoreje u Beogradu u periodu 2010-2014.godine}

\section{Sažetak}

Uvod. Svetska zdravstvena organizacija procenila je da je globalno u 2008. godini bilo 106,1 milion novoregistrovanih slučajeva gonoreje kod odraslih, od kojih su 3,4 miliona bili u evropskom regionu Svetske zdravstvene organizacije. U Evropskoj uniji i evropskom ekonomskom regionu, u 2012. godini ukupna učestalost prijavljenih slučajeva gonoreje iznosila je 15,3 na 100000 stanovnika. Najviša incidencija od 45,4 na 100000 utvrđena je u Velikoj Britaniji, dok su najniže stope ( $<5$ na 100000$)$ bile u Centralnoj i Istočnoj Evropi. U Srbiji je stopa u 2012. godini takođe bila niska i iznosila je 1,49.

Cilj. ovog rada bio je da se u Beogradu, glavnom gradu Srbije koji broji oko 1,5 miliona stanovnika, prati kretanje godišnje stope u periodu 2010-2014. godine i da se dobijeni podaci porede sa kretanjem stope u Evropskoj uniji u istom periodu.

Materijal i metode. Prijavljivanje svakog novootkrivenog slučaja gonoreje u Srbiji je zakonska obaveza. U Beogradu se svi slučajevi laboratorijski potvrđene gonoreje prijavljuju Gradskom zavodu za javno zdravlje, te su ovi izveštaji korišćeni kao izvor podataka. Za izračunavanje incidencije korišćeni su podaci za beogradsko stanovništvo iz popisa stanovništva Srbije iz 2011. godine. Standardizacija godišnjih stopa po starosnom dobu vršena je direktnom metodom uz svetsku populaciju kao standard.

Rezultati. U periodu od 2010. do 2014. godine prosečna incidencija gonoreje u beogradskoj populaciji iznosila je 9,2 na 100000 stanovnika za muškarce i 1,9 na 100000 stanovnika za žene. Kod oba pola incidencija je bila najveća u starosnom dobu od 20 do 29 godina. U svim uzrasnim grupama, incidencija gonoreje bila je veća za muškarce nego za žene i prosečan odnos među polovima bio je 4,8 u ,korist“ muškaraca. Među pripadnicima oba pola, infekcija je bila češća kod neoženjenih/neudatih lica, osoba sa srednjom stručnom spremom i kod nezaposlenih. Od ukupno 387 muškaraca obolelih od gonoreje $92(25,77 \%)$ su bili muškarci koji imaju seksualne odnose sa muškarcima.

Diskusija. Dramatični pad učestalosti gonoreje u Beogradu zabeležen je tokom poslednje dve decenije prošlog veka, stopa od 53, koliko je iznosila 1988. godine, pala je na 8 u 2000. godini. Isti trend nastavljen je i u prvoj deceniji novog milenijuma, kada je stopa iznosila 5. Međutim, od 2011. godine, učestalost se povećava i stopa raste od 2,47 koliko je iznosila u 2010. godini do 8,25 u 2013. i 7,17 u 2014 . godini.

Sličan trend incidencije gonoreje utvrđen je u novom milenijumu i u Evropskoj uniji: tokom prve decenije stopa pada sa 16,6 koliko je iznosila u 2003. godini na 9,65 u 2008. godini, da bi potom počela da raste, pa je od 2008. do 2014. godine zabeležen porast za $62 \%$, sa 10 na 16 koliko je iznosila stopa u 2012. godini.

Ne postoji jasno objašnjenje za trend pada učestalosti gonoreje u Beogradu tokom poslednje dve decenije dvadesetog veka, ali on može odražavati promene $u$ zdravstvenim sistemima, uključujući privatizaciju u zdravstvu, a samim tim i značajno veći broj neprijavljenih infekcija. Takođe, sve je bio veći broj privatnih apoteka u kojima je kupovina antibiotika bila dozvoljena bez lekarskog recepta, što je istovremeno otvorilo mogućnost tzv. samolečenja i „maskiranja“ infekcije, tj. dijagnoze. Takođe, usledile su promene u seksualnom ponašanju kao odgovor na epidemiju AIDS-a, naročito među muškarcima koji su imali seks sa muškarcima (MSM). Promena u seksualnom ponašanju podrazumevala je smanjenje broja partnera i usvajanje bezbednije seksualne prakse.

Kao što je već navedeno, nedavni porast incidencije gonoreje u Beogradu tokom 2010-2014. godine sličan je onom koji je registrovan u mnogim drugim evropskim zemljama. On se u Evropi može delom pripisati povećanju upotrebe senzitivnijih dijagnostičkih testova, kao što su test-amplifikacije nukleinske kiseline (NAATs) i uzorkovanje materijala sa više različitih anatomskih regija (npr. rektum, ždrelo) kad MSM. Istovremeno na drugoj strani, zahvaljujući sve efikasnijoj antiretrovirusnoj terapiji smanjivao se strah od infekcije HIV-om i učestalost seksualnog ponašanja sa visokim rizikom za prenošenje seksualno-prenosivih oboljenja ponovo je rasla, posebno među homoseksualcima. Povećanje incidencije gonoreje u Beogradu može se pripisati 
i činjenici da je od 2008. godine, počelo da radi prvo novoosnovano Savetovalište pri Odeljenju za seksualno prenosive bolesti u Gradskom zavodu za kožne i venerične bolesti u Beogradu, gde su pacijenti imali mogućnost pregleda bez uputa svog lekara. Odeljenje je prijateljski orijentisano ka ugroženom stanovništvu (MSM, pacijenti koji žive sa HIV-om, seksualne radnice), tako da je i broj onih koji su prijavljivali partnerstvo rastao. Istovremeno, zbog nepovoljne ekonomske situacije, broj pacijenata koji su mogli da priušte posetu privatnim lekarima je smanjen i samim tim verovatno je to jedan od razloga što se smanjio i broj neprijavljenih slučajeva. Većina registrovanih slučajeva gonoreje u Beogradu (95\%) tokom 2010-2014. godine je iz Gradskog zavoda za kožne i venerične bolesti.

Veća učestalost gonoreje kod muškaraca nego kod žena u Beogradu i u Evropskoj uniji, može se objasniti razlikama u seksualnom ponašanju i u kliničkim manifestacijama oboljenja koje postoje između žena i muškaraca. Poznato je da kod muškaraca homoseksualaca postoji povišen rizik za nastanak seksualno prenosivih infekcija, uključujući i gonoreju. Više od četvrtine muškaraca sa gonorejom u Beogradu deklarisalo se kao homoseksualac. Muškarci koji imaju seks sa muškarcima čine čak 38\% svih slučajeva gonoreje prijavljenih u 2012. godini u Evropskoj uniji. U ovoj studiji je najviša stopa gonoreje kod muškaraca i žena utvrđena u starosnoj grupi 20-29 godina, što je u skladu sa rezultatima dobijenim iz Evropske unije. Pojava viših stopa kod mlađih starosnih grupa može se objasniti većom slobodom seksualnog ponašanja kod mlađih osoba i biološkim razlikama koje utiču na ishod infekcije. Prema našim rezultatima, kod oba pola gonoreja je bila najčešća kod osoba koje nikada nisu bile u braku, koje su imale srednju školsku spremu i koje su bile nezaposlene. Poznato je da nizak nivo obrazovanja, mlađe životno doba i nizak socio-ekonomski status predstavljaju faktore rizika za nastanak gonokokne infekcije.

Zaključak. Slabost ove analize se odnosi se na preciznost podataka, s obzirom na potcenjen broj slučajeva gonoreje u Beogradu za šta postoji nekoliko mogućih razloga: postoji mogućnost da izvestan broj inficiranih nije posetio lekara, da neki lekari ne prijavljuju sve slučajeve i da dijagnoza gonoreje ponekad nije uspešna zbog nedostatka adekvatnih laboratorijskih mogućnosti.

Ključne reči: Gonoreja; Incidencija; Starosna struktura; Polna struktura; Homoseksualnost kod muškaraca; Seksualno ponašanje 